\title{
Paleontology of Taquaral Member silty shale in the State of São Paulo
}

\author{
Paleontologia do folhelho síltico do \\ Membro Taquaral no Estado de São Paulo
}

Artur Chahud*, Setembrino Petri

\begin{abstract}
The Irati Formation, Permian (Cisularian) from Brazilian Paraná Basin, at the State of São Paulo, is divided into two members: Taquaral (basal) and Assistência (top). The Taquaral Member exhibits two facies: basal, composed by sandstones and conglomerates, $0.1-1 \mathrm{~m}$ thick, and silty shales, $5-30 \mathrm{~m}$ thick. The few papers dealing with the paleontology of the silty shale facies are scarce so the main goal of this work was to widen the knowledge of the fossils of this unit. The reported fossils herein related are acritarchs, algae, crustaceans of the genus Clarkecaris and forms taxonomically indeterminate, besides and loose vertebrate remains. Other fossils and microfossils are reported in literature but without descriptions or illustrations. The fossil record of the silty shale allowed to put forth a paleoenvironmental suggestion of a restricted low salinity body of water.
\end{abstract}

KEYWORDS: Crustacea; Paraná Basin; Permian; Coelacanthimorpha; Osteichthyes.

\section{INTRODUCTION}

The Irati Formation is one of the Brazilian best known Paraná Basin lithostratigraphic unit, because of the dark shales with Mesosauridae remains. However, this unit exhibits different fossils and paleoenvironments.

Two members make up this formation, the basal Taquaral and the Assistência (Barbosa \& Gomes 1958, Milani et al. 2007, Holz et al. 2010). The Mesosauridae are present only at the upper beds of the Assistência Member.

The Taquaral Member deposits are mostly clayey non-betuminous shales, dark gray when unweathered, bearing small pyrite crystals. They are fissile parallel laminated, but as the laminae are thin, sometimes they are not clearly seen.

Sometimes, conglomeratic and fine sandstones are present in the lower portion of the member. These sandy beds bear great amount of isolated vertebrate pieces, part of them
RESUMO: A Formação Irati, unidade permiana do Cisulariano da Bacia do Paraná, é dividida, no Estado de São Paulo, por dois membros: Taquaral (basal) e Assistência (topo). O Membro Taquaral possui duas fácies. A basal é composta por arenitos e por conglomerados, variando de 0,1 - 1 m de espessura, e a segunda é constituida, predominantemente, por folhelhos silticos de $5-30 \mathrm{~m}$ de espessura. Pouco se conhece da paleontologia da fácies folhelho síltico. A ampliação deste conhecimento constituiu o principal objetivo deste trabalho. Os fósseis aqui relacionados incluem acritarcos, algas, crustáceos do gênero Clarkecaris e formas taxonomicamente indeterminadas, além de restos desarticulados de vertebrados. Outros fósseis e microfósseis são citados na literatura, mas sem descrições ou ilustrações. O conteúdo paleontológico da fácies folhelho síltico permitiu a sugestão paleoambiental de um corpo de água restrito e de baixa salinidade.

PALAVRAS-CHAVE: Crustacea; Bacia do Paraná; Permiano; Coelacanthimorpha; Osteichthyes.

recently taxonomically described (Chahud 2007, Chahud \& Petri 2008, 2010, Chahud et al. 2010; Chahud et al. 2012).

The present contribution discloses the up-to-date paleontologic fossils of the silty shale facies of the Taqural Member and, based on them, offers hypothesis for paleoenvironmental and paleoecological conditions.

\section{MATERIALS AND METHODS}

The study was based on outcrops from the municipality of Rio Claro, Center-East region of the State of São Paulo (Fig. 1). The fossils come from the Taquaral shales, which are predominant in the Taquaral Member.

The described and illustrated specimens were registered at the Scientific Collections of the Systematic Paleontology Laboratory (LPS) of The Institute of Geosciences, University of São Paulo.

Instituto de Geociências, Departamento de Geologia Sedimentar e Ambiental, Universidade de São Paulo - USP, São Paulo (SP), Brasil. E-mails: arturchahud@yahoo.com, spetri@usp.br

*Autor correspondente

Manuscrito ID 27091. Recebido em: 22/05/2012. Aprovado em: 24/09/2012 


\section{CRUSTACEAN}

The crustacean of the genus Clarkecaris was found out in the Taquaral Member shale. Every specimen is characterized by narrow and elongated bodies.

The thoracic somites are smooth, without ornamentation, as it can be seen at the specimens GP/1E-5691, GP/1E-5689 and GP/1E-5692 (Figs. 2A to C). The abdominal somites are wide, bearing small spines at the extremities, turned backward (Figs. 2A and E) (GP/1E-5691 e GP/1E-5690a).

This taxon first found out from Guareí Municipality, State of São Paulo, was identified by Clarke (1920) as Gampsonix brasilicus. Mezzalira (1952), in a revision of this taxon, proposed a new genus, Clarkecaris (species Clarkecaris brasilicus), within the familiy Uronectidae.

Brooks (1962), based on a specimen deposited at a collection of the U.S. National Museum, did not agree that this genus would belong to the family Uronectidae. Brooks remarked that it exhibits peculiar features, deserving a proper family, Clarkecarididae, within the order Anaspidacea, but without clear relationship with the living Anaspidacea.

Pinto (1985) published the most complete description of this taxon, detailing it with the morphological features of cephalothorax, abdomen and telson.

Clarkecaris brasilicus (Clarke) is endemic in the States of São Paulo and Paraná. It does not occur in other localities of the Paraná Basin. The paleoenvironments where Clarkecaris lived are polemic - water saline or freshwater. Beurlen (1931) admitted the possibility of freshwater paleoenvironment, based on the living Anaspidacea, Anaspidites, but this argument is not enough.

Mezzalira (1952) discussed the Clarkecaris paleoenvironment but, in spite of its phylogenetic allocation near

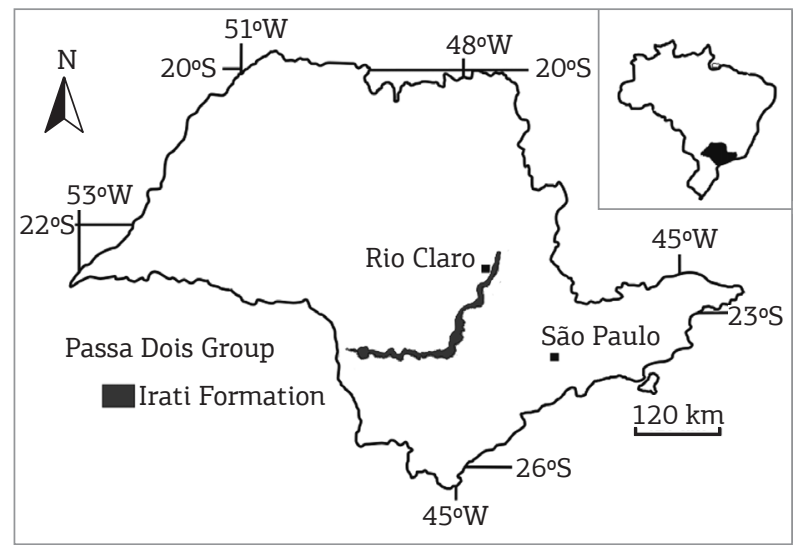

Figure 1. Irati outcrop belt in the State of São Paulo.
Anaspidites, he did not feel sure about the paleoenvironment where Clarkecaris lived.

Both Beurlen (1931) and Mezzalira (1952) believed that this taxon probably lived in coast environments but not offshore because of its presence only in Taquaral sediments near the border of Paraná Basin.

Schram \& Schram (1974) compared Clarkecaris brasilicus with the Carboniferous Syncarida Palaeocaridacea Squillites and Palaeocaris. According to these authors, Clarkecaris would be a transitional form between the older more primitive Palaeocaridacea and the living Anaspidacea genus Anaspidites.

Other crustacean taxon was found out, associated with Clarkecaris. Only the carapace with two appendicular members, bifurcated at their extremities is preserved. Foehringer \& Langer (2003, 2004) and Chahud (2011) interpreted these bifurcate extremities as chelas. Foehringer \& Langer (2003, 2004), based on this feature, classified that form as Decapoda. This classification is not sure inasmuch as other Decapoda chelas, as well as other crustaceans, exhibit different kinds of chelas.

\section{VERTEBRATE}

The vertebrates are the most frequent fossils from the Taquaral silty shale facies but only bone fish remains are present (Actinopterygii and Sarcopterygii).

The Actinopterygii scales are the most common fossils and usually well preserved. They are rhombohedron in shape, smooth borders and generally without articulation, but sometimes "peg-and-socket" articulation systems are clearly seen (Figs. 3A and B). The scale sizes measure 0.5 to $15 \mathrm{~mm}$, both in length and width.

Few scales exhibit some kind of surface ornamentation. The specimen GP/2E-6222 (Fig. 3B) is one example of ornamented scale, but its poor preservation prevents a detailed description. Other Actinopterygii pieces are teeth, bones and connected parts, and maxillas (GP/2E-6231) (Fig. 3C).

Sarcopterygii are recognized only by isolated scales of Coelacanthidae, where the grouth lines and imbrication zone are preserved.

The imbrication region stretchs over one third of the scale, reinforced by several longitudinal ribs, some short, some long, sometimes overlapping but never branching (Fig. 3D).

As growth lines get together near the imbrication region, they become slightly curved. 

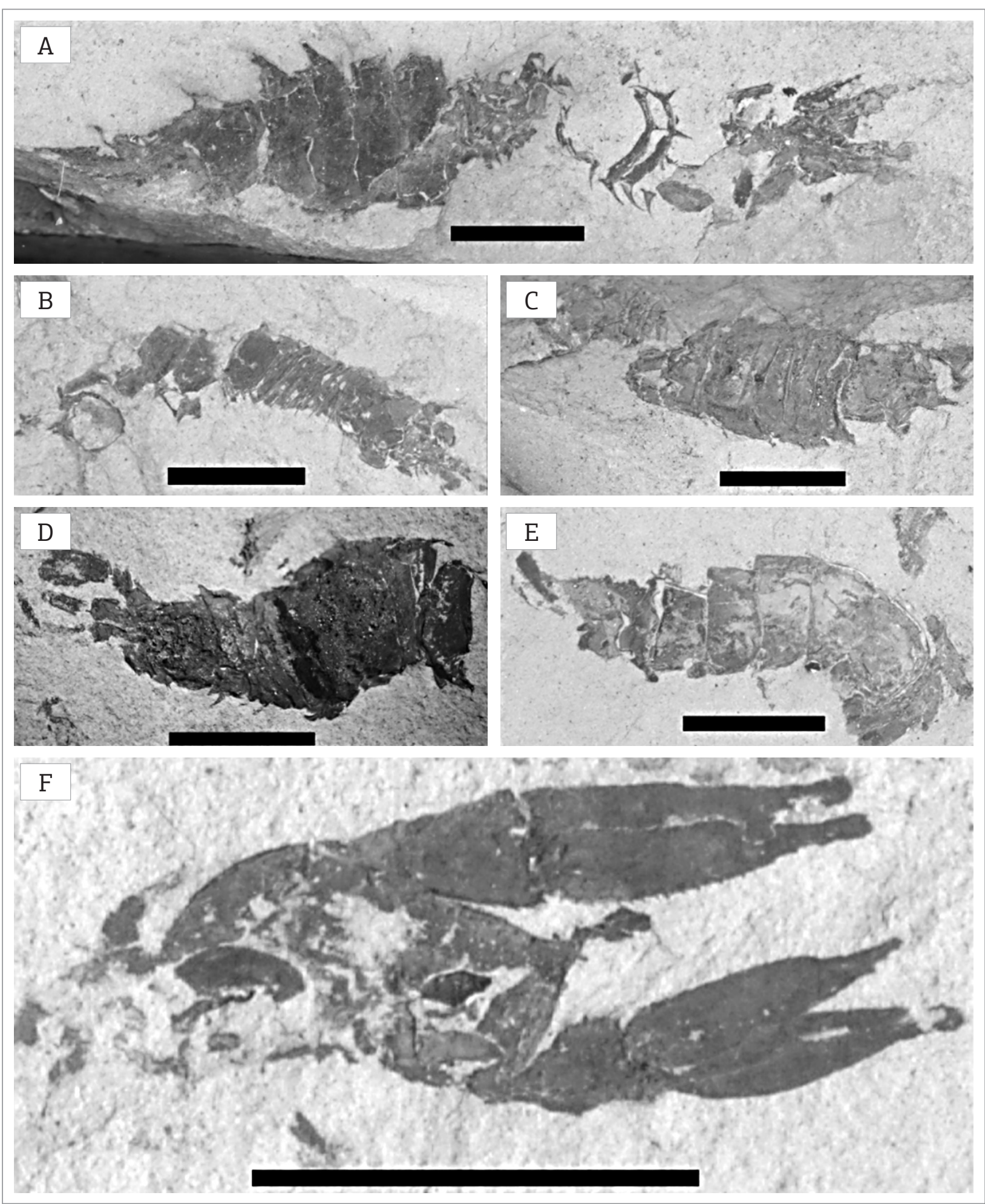

Figure 2. Specimens of Clarkecaris found out in Rio Claro. (A) GP/1E-5691; (B) GP/1E-5689; (C) GP/1E-5692; (D) GP/1E-5693; (E) GP/1E-5690a, Bar scale: 5 mm; (F) indeterminate crustacean. GP/1E-6174. Bar scale: $10 \mathrm{~mm}$.

The similarities of these described scales with those of the Coelacanthimorpha presently living in the Indian Ocean (Latimeria) justify their allocation with Coelacanthidae.
The herein studied Taquaral Coelacanthimorpha scales display similar shape growth lines and articulations with the Carboniferous and Permian Itararé Group from States of São Paulo (Bryant 1929, Barcellos 1975) and Rio Grande do 
Sul, Assistência Member, Irati Formation of the Rio Grande do Sul (Richter 1985) and the Corumbataí Formation, from the State of São Paulo, described by (Maranhão 1995).

\section{OTHER FOSSILS}

Other kinds of fossils are cited in papers either restricted to a unique citation or in few ones. Anyway, there are always simple references without descriptions and illustrations.

The presence of great amount of indeterminate Bivalvia, about $5 \mathrm{~mm}$ average length, were reported in thin calcareous beds, intercalated with shales, from the upper part of the Taquaral of the State of Paraná (Kazubek \& Simões 2003a; 2003b, Rohn et al. 2003, Lages 2004).

According to Hachiro (1996), the characteristics of these sediments are indicative of the upper half of the Taquaral or transition to Assistência Member in the State of Paraná.

Clarke (1920) reported gastropoda of the genera Loxonema and Bellerophon associated with the first described Clarkecaris. Beurlen (1931), studying Clarke's material, did not confirm the Gastropoda in his collection.

Some pollen grains, acritarch and the algae Bothryococcus were reported by several authors
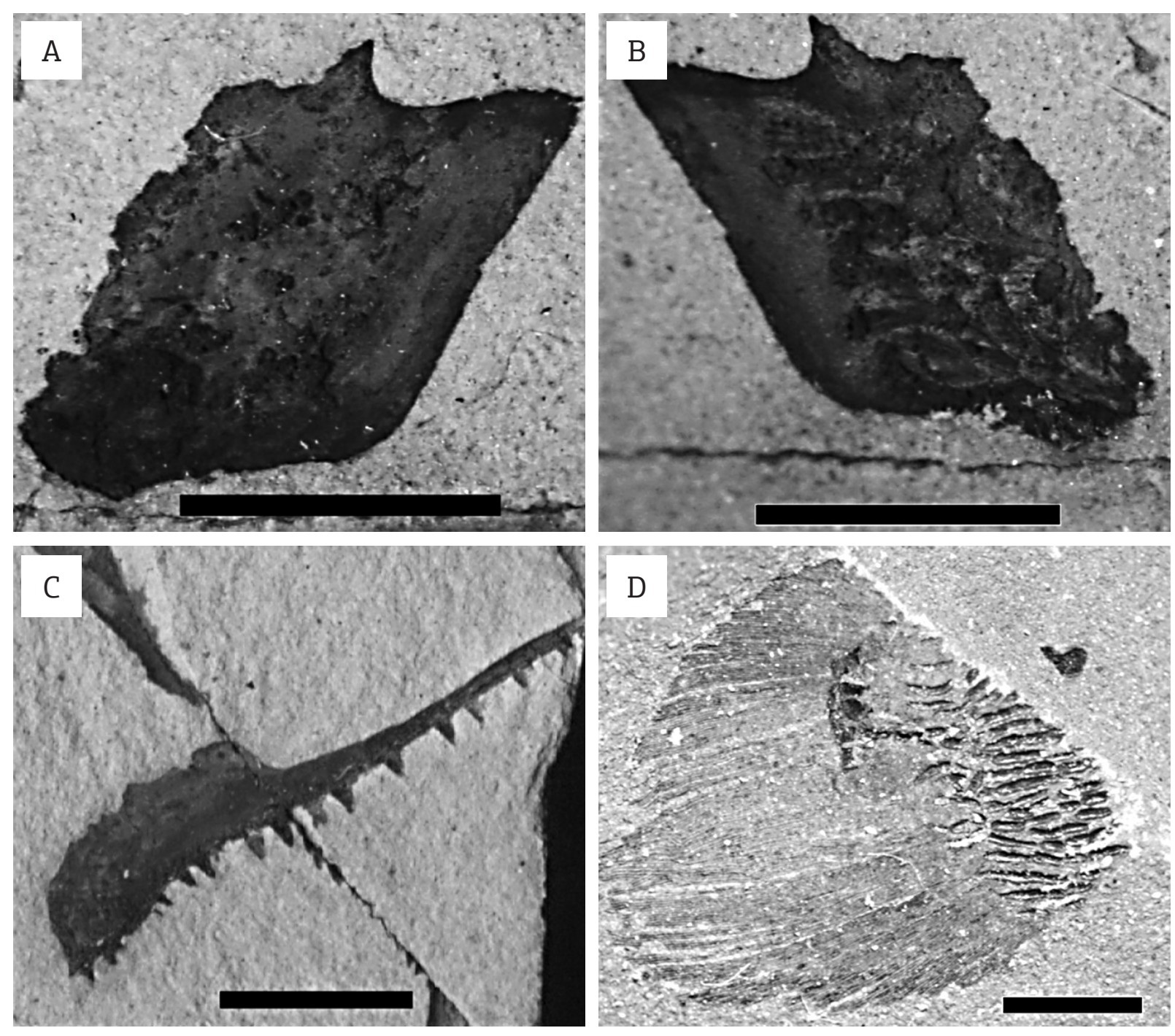

Figure 3. (A) Palaeonisciformes scale (GP/2E-6222a); (B) Counterpart of the scale "A" (GP/2E-6222b) with surface ornamentation and "peg-and-socket" articulation seen at the upper side Bar scales $2 \mathrm{~mm}$; (C) Palaeonisciformes maxilla (GP/2E-6231), Bar scale $4 \mathrm{~mm}$; (D) Coelacanthimorpha scale. Bar scale $10 \mathrm{~mm}$. 
(Cazzulo-Klepzig et al. 1989, Souza et al. 1992, Holz \& Dias 1998, Lages 2004, Cardoso 2010).

The mentioned Acritarch taxa tolerate variable salinities. The freshwater Bothryococcus is easily transported from rivers to the sea, so the mentioned fossils are not good paleoenvironmental index.

Campanha (1985) reported some fossils from a core of a well drilled at the municipality of Marília, State of São Paulo. Taquaral Member does not crop out at this municipality. The author cited Brachiopoda, Lingula, agglutinated foraminifera, Ammodiscus and Sorosphaera, ostracoda, Bairdia. Hachiro (1996) considered this core either the uppermost Taquaral Member or base of the Assistência Member. These fossils were not observed by other authors neither in cores nor in outcrops. They were neither described nor illustrated. According to Campanha in personal communication, the fossils are lost.

\section{PALEOENVIRONMENTAL CONSIDERATIONS}

No fossil known in the Taquaral beds are exclusively of marine paleoenvironments. Some of them supported variable salinity waters such as acritarchs, lingulids and possible agglutinated foraminifers. Similar groups of fossil were reported in Palermo, Tatuí or sandy basal of the Taquaral Member (Cazzulo-Klepzig et al. 1989, Marasco et al. 1993, Holz et al. 1998, Cardoso 2010).

These groups were able to adopt salinity variations, so some of them could survive the paleoenvironmental changes and persisted in the latest Taquaral Member times, at restricted conditions of the basin — as is the case in the present interior sea basins like the Caspian and the Aral (Zenkevitch 1957).

Eventual communications with the open ocean might have been occurred during the depositions of the Tatuí Formation, Palermo Formation (a formation rather synchronic with Tatuí, developed in Brazilian Paraná Basin states, Southern of the São Paulo State) and in the basal sandy beds of the Taquaral Member (Chahud \& Petri 2010, Chahud et al. 2012). These eventual sea communications might have been short in duration, inasmuch as the biotas of these formations are little diversified. Their characteristics are easy locomotion and proliferation capacities, so they were able to rapidly establish in the new paleoenvironment. Organisms living in "open ocean", like most of the Echinodermata, Bryozoa, Fusulinidae, calcareous foraminifers, Cephalopoda and corals, only thrive in open marine conditions. They need longer time and paleoenvironmental stability through continuous contact basin-ocean. The Black Sea is an example - older freshwater organisms were replaced by salty water organism as the sea encroached upon a lake paleoenvironment (Sorokin \& Kuprin 2007).

\section{CONCLUSIONS}

The most frequent fossils of the Taquaral Shales macrofauna are the crustaceous Clarkecaris, Osteichthyes scales and bone fragments. Among the bone fishes, the Palaeonisciformes are the most common. Actinistia fishes are rare.

The tetrapods and Chondrichthyes were not as yet found out in the shales. They are present in the Taquaral Member but only at its sandy basal beds. However, they appeared again at the uppermost Assistência Member beds of the Irati Formation and in the Corumbataí and Serra Alta formations younger than Irati (Würdig-Maciel 1975, Toledo 2001).

The Anaspidacea Clarkecaris is endemical in the Taquaral Member, present only at the State of São Paulo and Paraná. It may be evolved from salty water paleoenvironment and migrated to less salty water. With the probable confinement of the Taquaral basin, the family Clarkecaridae evolved in isolated conditions.

Any macro or microfossils but Clarkecaris known in the Taquaral shales are a sure paleoenvironmental index. The presence of euryhaline fossils and the absence of stenohaline and fossils suggest a low or variable salt content in the Taquaral basin, probably due to freshwater rivers, coming to the basin, as in the case of the Caspian Sea, an isolated body of water.

\section{ACKNOWLEDGEMENTS}

The authors thank Prof. Dr. Claudio Riccomini, Prof. Dr. Thomas Rich Fairchild and Master Felipe van Enck Meira for support and jointing field researches. The authors also thank Departamento de Geologia Sedimentar e Ambiental of the Institute of Geoscience of the University of São Paulo, which allowed the preparation of fossils in the laboratories and last, but not least, special thanks for CAPES, CNPq and FAPESP for financial support. 


\section{REFERENCES}

Barbosa O. \& Gomes F.A. 1958. Pesquisa de petróleo na bacia do rio Corumbataí, Estado de São Paulo. Boletim do DNPM/DGM, 171. Rio de Janeiro, Ministério da Agricultura, Departamento Nacional da Produção Mineral, Divisão de Geologia e Mineralogia, 40 p.

Barcellos M.T. 1975. Estudo de escamas e dentes de peixes da Fácies Budó, Sub-grupo Itararé, R.G.S. Boletim Paranaense de Geociências, 32:3-65.

Beurlen K. 1931. Crustaceenreste aus den Mesosaurierschichten (Unterperm) von Brasilien (São Paulo). Palaeontologische Zeitschr, 13:35-50.

Brooks H.K. 1962. On the fossil Anaspidacea, with a revision of the classification of the Syncarida. Crustaceana, 4(3):229-242.

Bryant W.L. 1929. Fossil fish remains from the Permian tillite of Brazil. Bulletin Geological Society American, 40:424-426.

Campanha V.A. 1985. Ocorrência de braquiópodos inarticulados na Formação Irati no Estado de São Paulo. Anais da Academia Brasileira de Ciências. Resumo de Comunicações, 57(1):115-116.

Cardoso T.R.M. 2010. Registro marinho no Membro Taquaral (Formação Irati), Permiano Superior da Bacia do Paraná, Brasil. In: Simpósio Brasileiro de Paleobotânica e Palinologia, 13., 2010. Salvador. Resumos, p. 143.

Cazzulo-Klepzig M., Piccoli A.E.M., Marques-Toigo M. 1989. Reconhecimento de um marco estratigráfico com significado paleoecológico no Permiano da Bacia do Paraná (Grupos Guatá e Passa Dois). In: Congresso Brasileiro de Paleontologia, 11., 1989. Curitiba. Anais ... 2, p. 971-982

Chahud A. 2007. Paleontologia de vertebrados da transição entre os grupos Tubarão e Passa Dois (neopaleozóico) no centro-leste do Estado de São Paulo. Dissertação de Mestrado, Instituto de Geociências, Universidade de São Paulo, São Paulo, 173 p.

Chahud A. 2011. Geologia e paleontologia das formações Tatuí e Irati no centro-leste do Estado de São Paulo. Tese de Doutorado, Programa de Pós-Graduação em Geoquímica e Geotectônica, Instituto de Geociências, Universidade de São Paulo, São Paulo, 299 p.

Chahud A., Fairchild T.R., Petri S. 2010. Chondrichthyans from the base of the Irati Formation (Early Permian, Paraná Basin), São Paulo, Brazil. Gondwana Research, 18(2-3):528-537.

Chahud A., Pacheco M.L.A.F., Meira F.E., Romero G.R., Petri S. 2012. Paleontology and depositional environments of the Tatuí and Irati formations (Permian) in the Ponte Nova Farm, Ipeúna, State of São Paulo. Revista Brasileira de Geociências, 42(1):198-212.

Chahud A. \& Petri S. 2008. Registro de Paleoniscóides na base do Membro Taquaral, Formação Irati, Permiano da Bacia do Paraná. Revista do Instituto Geológico, 29(1-2):33 - 40.

Chahud A. \& Petri S. 2010. Anfíbio e Paleonisciformes da porção basal do Membro Taquaral, Formação Irati (Permiano), Estado de São Paulo, Brasil. Geologia USP. Série Científica, 10(1):29-37.

Clarke J.M. 1920. Crustacea from the Permian of Sao Paulo, Brazil. Bulletin of the New York State Museum, 219-220:135-137.

Foehringer K.J.A. \& Langer M.C. 2003. A descoberta de um decápodo reptântio (Crustacea, Malacostracea) na Formação Irati (Permiano da Bacia do Paraná). In: Congresso Brasileiro de Paleontologia, 18. 2003. Brasília. Boletim de Resumos, v. 1, p.132-133.

Foehringer K.J.A. \& Langer M.C. 2004. Relações do crustáceo reptântio da Formação Irati (Permiano Superior) In: Paleo 2004, 1., São Carlos. Boletim de Resumos,12.

Hachiro J. 1996. O Subgrupo Irati (Neopermiano) da Bacia do Paraná. Tese de Doutorado, Programa de Pós-Graduação em Geologia Sedimentar, Instituto de Geociências, Universidade de São Paulo, São Paulo, 196 p.
Holz M. \& Dias M.E. 1998. Taphonomy of palynological records in a sequence stratigraphic framework: an example from the Early Permian Paraná Basin of Southern Brazil. Review of Palaeobotany and Palynology, 99(3-4):217-233.

Holz M., França A.B., Souza P.A., Iannuzzi R., Rohn R. 2010. A stratigraphic chart of the Late Carboniferous/Permian succession of the eastern border of the Parana Basin, Brazil, South America. Journal of South American Earth Sciences, 29(2):381-399.

Holz M., Zwetsch G., Simões M.G., Carlucci R. 1998. Tafonomia dos invertebrados na Formação Palermo (Kunguriano) da Bacia do Paraná no Rio Grande do Sul: lingulídeos desarticulados em fácies de tempestitos. In: Congresso Brasileiro de Geologia, 40., 1998. Belo Horizonte. Anais ..., p. 453.

Kazubek M.F. \& Simões M.G. 2003a. Permian bivalves of the Irati Formation (Passa Dois Group, Paraná Basin) and their paleoecological significance. In: Congresso Brasileiro de Paleontologia, 18., Brasília. Boletim de Resumos, p. 161.

Kazubek M.F. \& Simões M.G. 2003b. Feições sedimentológicas, bioestratinômicas e estratigráficas das concentrações de bivalves do Membro Taquaral (Formação Irati, Grupo Passa Dois, Bacia do Paraná) e seus significados. In: Paleo-2003. PR-SC. Paleontologia em Destaque. Curitiba, v. 44, p. 29.

Lages L.C. 2004. A Formação Irati (Grupo Passa Dois, Permiano, Bacia do Paraná) no furo de sondagem FP-01-PR (Sapopema, PR). Dissertação de Mestrado, Pós-Graduação em Geociências, Instituto de Geociências e Ciências Exatas, Universidade Estadual Paulista "Júlio de Mesquita Filho", Rio Claro, 117 p.

Maranhão M.S.A.S. 1995. Fósseis das Formações Corumbataí e Estrada Nova do Estado de São Paulo: Subsídios ao conhecimento Paleontológico e Bioestratigráfico. Tese de Doutorado, Programa de Pós-Graduação em Geologia Sedimentar, Instituto de Geociências, Universidade de São Paulo,São Paulo, 79 p. 2 v.

Marasco S.A., Souza P.A., Pires F.A. 1993. Ocorrência de paleomicroplâncton marinho (Acritarcha) associados a ictiofósseis na base do Membro Taquaral, Formação Irati (Permiano Superior da Bacia do Paraná), região de Itapetininga, Estado de São Paulo. In: Congresso Brasileiro de Paleontologia, 13., I Simpósio paleontológico do Cone Sul, São Leopoldo, RS. Sociedade Brasileira de Paleontologia, UNISINOS, Boletim de Resumos, p. 60.

Mezzalira S. 1952. Clarkecaris, novo gênero de crustáceo Syncarida do Permiano. Revista da Sociedade Brasileira de Geologia, 1(1):46-51

Milani E.J., Melo J.H.G., Souza P.A., Fernandes L.A., Franca A.B. 2007. Bacia do Paraná. Cartas Estratigráficas - Boletim de Geociências da Petrobras, 15(2):265-287.

Pinto I.D. 1985. New data on the genus Clarkecaris Mezzalira, 1952 (Malacostraca) from Brazil. In: Coletânea de Trabalhos Paleontológicos. DNPM, Série Geologia. Seção de Paleontologia e Estratigrafia, 2(27):253-259.

Richter M. 1985. Situação da Pesquisa Paleoictiológica no Paleozóico Brasileiro. In: Coletânea de Trabalhos Paleontológicos. DNPM, Série Geologia. Seção de Paleontologia e Estratigrafia, 2(27):105-110.

Rohn R., Lages L.C., Penatti J.R.R. 2003. Litofácies da Formação Irati no Furo de sondagem FP-01-PR (Permiano, borda leste da Bacia do Paraná). In: Congresso Brasileiro de P\&D em Petróleo \& Gás, 2., 2003. Rio de Janeiro. Resumos. Universidade Federal do Rio de Janeiro, 1:1-6. 
Schram J.M. \& Schram F.R. 1974. Squillites spinosus Scott 1938 (Syncarida Malascostraca) from the Mississippian Heath shale of Central Montana. Journal of Paleontology, 48(1):95-104.

Sorokin V.M. \& Kuprin P.N. 2007. On the character of Black Sea level rise during the Holocene. Moscow University Geology Bulletin, 62(5):334-341.

Souza P.A., Santos P.R., Lima M.R. 1992. Contribuição à palinologia da Formação Irati no Estado de Goiás. In: Congresso Brasileiro de Geologia, SBG, 37., 1992. São Paulo. Boletim de Resumos Expandidos, 2:485-486

Toledo C.E.V. 2001. Análise paleontológica da Formação Corumbataí na Região de Rio Claro, Estado de São Paulo. Dissertação de Mestrado,
Instituto de Geociências e Ciências Exatas, Universidade Estadual Paulista “Júlio de Mesquita Filho", Rio Claro, 146 p.

Würdig-Maciel N.L. 1975. Ichtiodontes e ichtiodorulitos (Pisces) da Formação Estrada Nova e sua aplicação na estratigrafia do Grupo Passa Dois. Pesquisas, 5:7-165.

Zenkevitch L. 1957. Caspian and Aral Seas. In: Hedgpeth J.W. (ed.), Treatise on marine ecology and paleoecology. Memoires of the Geological Society of America. Geological Society of America, Memoire 67, 1, p. 891-916.

$\overline{\text { Arquivo digital disponível on-line no site www.sbgeo.org.br }}$ 